\title{
Formulation and evaluation of buccoadhesive quetiapine fumarate tablets
}

\author{
Appa Rao Potu*, Naresh Pujari, Shashidher Burra, Prabhakar Reddy Veerareddy \\ Department of Pharmaceutics, St. Peter's Institute of Pharmaceutical Sciences, Vidyanagar, Hanamkonda,Warangal,Andhra \\ Pradesh, India
}

\begin{abstract}
The aim of present study was to develop and evaluate buccoadhesive Quetiapine Fumarate (QF) tablets, which is extensively metabolised by liver. Buccoadhesive tablets of QF were prepared using HPMC K4M, HPMC K15M and combination of carbopol and HPC as mucoadhesive polymers by direct compression method. Sodium deoxycholate was added to formulation to improve the permeation of drug. The formulations were tested for bioadhesion strength, ex vivo residence time, swelling time and in vitro dissolution studies and ex vivo permeation studies. Optimized formulation (F3) showed $92 \%$ in vitro release in $8 \mathrm{~h}$ and $67 \%$ permeation of drug through porcine buccal mucosa and followed fickian release mechanism with zero order kinetics. FTIR studies of optimized formulation showed no evidence of interaction between the drug and polymers. In vivo mucoadhesive behaviour of optimized formulation was performed and subjective parameters were evaluated.
\end{abstract}

Uniterms: Quetiapine Fumarate. Bioadhesion. In vivo mucoadhesive behaviour.

O objetivo do presente estudo foi desenvolver e avaliar os comprimidos bucoadesivos de fumarato de quetiapina (FQ), que é extensivamente metabolizada no fígado. Os comprimidos bucoadesivos de FQ foram preparados utilizando-se HPMC K4M, HPMC K15M e a combinação de carbopol e HPC como polímeros mucoadesivos pelo método de compressão direta. O desoxicolato de sódio foi adicionado à formulação para melhorar a permeação do fármaco. As formulações foram testadas quanto à força de bioadesão, tempo de residência ex vivo, tempo de inchamento, dissolução in vitro e permeação ex vivo. A formulação otimizada (F3) mostrou $92 \%$ de liberação in vivo em 8 h e $67 \%$ de permeação do fármaco através da mucosa bucal de porco e seguiu o mecanismo fickiano de liberação com cinética de ordem zero. Os estudos de FTIR da formulação otimizada não mostraram evidência da interação entre o fármaco e os polímeros. O comportamento mucoadesivo in vivo da formulação otimizada foi efetuado e avaliaram-se os parâmetros subjetivos.

Uniterms: Fumarato de quetiapina. Bioadesão. Comportamento mucoadesivo in vivo.

\section{INTRODUCTION}

Bioadhesive buccal drug delivery provides an attractive alternative to the oral route of drug administration particularly overcoming deficiencies such as high first-pass metabolism and drug degradation in the harsh gastrointestinal environment (Gibaldi, 1985; Senel, Hincal, 2001). The stratified squamous epithelium supported by a connective tissue lamina of buccal mucosa was targeted as

\footnotetext{
*Correspondence: Appa Rao Potu. Department of Pharmaceutics, St. Peter's Institute of Pharmaceutical Sciences, Vidyanagar, Hanamkonda,Warangal, Andhra Pradesh, India-506001. E-mail: arrpotu@yahoo.com
}

a site for drug delivery (Squier, Wertz, 1996). Buccal drug delivery provides a number of advantages like robustness of epithelium, usage of the dosage form in accordance with need, good accessibility and comparatively less susceptibility to enzymatic activity (Shanker et al., 2009) and can administer drugs to patient who cannot be dosed orally to prevent accidental swallowing (Vamshi Vishnu et al., 2007). Therefore, adhesive mucosal dosage forms were developed for oral delivery, in the form of adhesive tablets (Schor et al., 1983; Owens, Dansereau, Sakr, 2005; Akbari et al., 2004), adhesive gels (Bremecker, Strempel, Klein, 1984; Ishida, Vambu, Vagai, 1983; Packer et al., 2001) and adhesive patches (Guo, 1994; Anders, Merkle, 1989). 
The major limiting factor for development of Bioadhesive buccal delivery devices is the permeation of drug through membrane. The main barrier for the absorption of drug is the epithelium of the buccal mucosa. To improve absorption through buccal mucosa, several approaches have been investigated. By changing the physicochemical properties of the drug, increased permeation of the drug through the buccal membrane and prevention of drug degradation by enzyme was achieved (Shojaei, 1998). The amount of drug available for absorption was increased by improving the bioadhesion and release characteristics of buccal delivery (Nagai, Machida, 1985). Addition of permeation enhancers is one of the approaches. Substances that facilitate the permeation through buccal mucosa are referred as permeation enhancers. Incorporation of permeation enhancers improves the delivery of drug via buccal membrane, which could reduce barrier properties of the buccal epithelium (Aungst, Rogers, 1989; Lee, Yamamoto, Kompella, 1991; Pitha, Harman, Michel, 1986; Burnside, Keith, Snipes, 1989; Zhang et al., 1994; Steward, Bayley, Howes, 1994; Ebert et al., 1994; Hoogstraate et al., 1997).

Quetiapine Fumarate (QF), 2-[2-(4-dibenzo $[b, f]$ [1,4]thiazepin-11-yl-1-piperazinyl)ethoxy]-ethanol fumarate $(2: 1)$ (salt), is an atypical psychotropic agent belonging to a class dibenzothiazepine derivate. It is used in the treatment of schizophrenia and manic episode associated with bipolar I disorder (Bhanudas, Sanjay, 2009). The peak plasma concentration is reached with in $1.5 \mathrm{~h}$. The bioavailability of QF is about $9 \%$ and half life is $6 \mathrm{hr}$ and is widely distributed through out the body and $83 \%$ of drug binds to plasma proteins. It is extensively metabolised in liver to the sulfoxide metabolite and parent acid metabolite by sulfoxidation and oxidation; both metabolites are pharmacologically inactive leading to lower bioavailability. So, QF is selected as model drug for Bioadhesive buccal drug delivery to overcome extensive first-pass metabolism.

The aim of present study was to develop buccoadhesive QF tablets to enhance bioavailability of drug.

\section{MATERIAL AND METHODS}

\section{Material}

Quetiapine Fumarate (QF) is a gift sample from Matrix Laboratories, Hyderabad, India. Hydroxypropyl methylcellulose (HPMC K4M, HPMC K15M) and perlitol S.D. 200 are gift samples from Dr. Reddy's Laboratories, Hyderabad. Carbopol 934P was purchased from S. D. Fine Chem. Ltd., Mumbai, India. Hydroxy propyl cellulose (HPC) was donated by Natco Pharma, Hyderabad, India. Sodium deoxycholate was purchased from Moly Chem.,
Mumbai, India. All other chemicals and reagents used were of analytical grade.

\section{Methods}

\section{Solubility studies}

Quetiapine Fumarate (QF) solubility studies in phosphate buffer, $\mathrm{pH} 6.6$ was determined by phase equilibrium method. An excess amount of QF was taken in $20 \mathrm{~mL}$ vial containing $10 \mathrm{~mL}$ of phosphate buffer, $\mathrm{pH}$ 6.6. These vials were closed with rubber caps and agitated at room temperature for $24 \mathrm{~h}$ using rotary shaker (Remi Instruments, Mumbai, India). The solution was filtered through a $0.2 \mu \mathrm{m}$ whatman filter paper after $24 \mathrm{~h}$. The amount of drug solubilized was estimated by measuring absorbance at $250 \mathrm{~nm}$ using a UV spectrophotometer (Systronic PCBased Double Beam Spectrophotometer 2202, Ahmedabad, India) (Gupta, Garg, Khar,1993). The studies were repeated in triplicate $(n=3)$ and mean was calculated.

\section{Tissue isolation}

Buccal tissue of domestic pork was taken from a local slaughter house and was stored in Krebs buffer, pH 7.4 at $4{ }^{\circ} \mathrm{C}$ upon collection. The epithelium was separated from the underlying connective tissue with a surgical procedure. The membrane was mounted within $24 \mathrm{~h}$ of isolation of buccal tissue over Franz diffusion cell.

\section{Ex vivo permeation of drug solution}

Ex vivo permeation of drug solution through the porcine buccal membrane was studied. The buccal epithelium was carefully mounted over a Franz diffusion cell with an internal diameter of $2.4 \mathrm{~cm}\left(4.52 \mathrm{~cm}^{2}\right.$ area $)$ and with a receptor compartment volume of $14 \mathrm{~mL}$, It is filled with phosphate buffer, $\mathrm{pH}$ 6.6. After the buccal membrane was equilibrated for 30 min with buffer solution, the receptor chamber was filled with fresh phosphate buffer solution (pH 6.6) and the donor chamber was charged with $(5 \mathrm{~mL})$ buffer solution. The entire setup was placed over magnetic stirrer (Remi, 2MLH, Mumbai, India) at $50 \mathrm{rpm}$ and temperature was maintained at $37 \pm 0.2{ }^{\circ} \mathrm{C}$. Aliquots samples $(1 \mathrm{~mL})$ were collected at predetermined intervals up to $8 \mathrm{~h}$ and the amount of drug permeated through the buccal mucosa was then determined at $250 \mathrm{~nm}$ using UV spectrophotometer. The experiment was repeated in triplicate $(n=3)$ and mean values were calculated. The cumulative amount of the permeated drug was plotted against time. The flux $(\mathrm{J})$ and the permeability coefficient $(\mathrm{P})$ were calculated by using the following equations (1) and (2).

$$
\mathrm{J}=\mathrm{dQ} / \mathrm{dt}
$$




$$
\mathrm{P}=(\mathrm{dQ} / \mathrm{dt}) \Delta \mathrm{CA}
$$

Where $\mathrm{J}$ is flux $\left(\mathrm{mg} \mathrm{h}^{-1} \mathrm{~cm}^{-2}\right)$; $\mathrm{P}$ is permeability coefficient $\left(\mathrm{cm} \mathrm{h}^{-1}\right) ; \mathrm{dQ} / \mathrm{dt}$ is the slope obtained from the steady-state portion of the curve; $\Delta \mathrm{C}$ is the concentration difference across the mucosa and $\mathrm{A}$ is the area of diffusion $\left(\mathrm{cm}^{2}\right)$.

\section{Buccoadhesive tablet preparation}

Buccoadhesive tablets were prepared as shown in Table I by direct compression method. Prior to direct compression, QF mixed manually with polymers and perlitol S. D. 200 as a filler and was screened through sieve No. 40 and then lubricants (talc and magnesium stearate) were added. Blending for core and backing layer was carried out separately. First, the backing layer was compressed using $8.0 \mathrm{~mm}$ flat faced punches on Cadmach rotary tablet machine (Cadmach, Ahmedabad, India). Then powder of core layer was added to previously obtain backing layer and compressed again (Shanker et al., 2009).

\section{Thickness}

The thickness of tablets was determined using digital caliper (Aerospace, India). Ten individual tablets were measured and the average thickness was calculated.

\section{Weight variation}

Weight variation test was carried out for ten tablets of each batch using an electronic balance (Shimadzu, Aux*200, Japan) and average values were calculated.

\section{Hardness}

Hardness for three tablets of each batch was mea- sured by using Monsanto hardness tester and average values were calculated.

\section{Assay}

Ten tablets were selected randomLy and were powdered in a mortar with pestle; powder equivalent to the mass of one tablet was dissolved in methanol by sonication for $30 \mathrm{~min}$ and filtered through $0.2 \mu \mathrm{m}$ whattman filter paper. The drug content was analyzed at $250 \mathrm{~nm}$ using a UV-Visible spectrophotometer. The experiment was carried out in triplicate and mean drug content was calculated.

\section{In vitro bioadhesion studies}

Bioadhesion strength of the tablets was determined on a modified physical balance (Shanker et al., 2009; Gupta, Garg, Khar, 1993). This apparatus consists of a modified double beam physical balance in which right pan was replaced with a lighter pan and the left pan was replaced with a glass slide ( $4 \mathrm{~cm}$ length and $2.5 \mathrm{~cm}$ width) which was suspended by means of Teflon rings and copper wire. The setup was balanced in such a way that it consists of $5 \mathrm{~g}$ of removable weights on right pan and equivalent amount of clay on other side. The height of the total setup was adjusted so as to accommodate a glass container of $6.6 \mathrm{~cm}$ height. To find bioadhesion strength, buccal tablet was stack to the glass slide with cyanoacrylate adhesive and balance was set in to weighing mode with the help of a knob that is situated at the base of the balance. Now, $5 \mathrm{~g}$ of weight on the right pan is removed. This lowered the glass slide along with the tablet over the membrane with a weight of $5.0 \mathrm{~g}$. The entire setup was kept undisturbed for $5 \mathrm{~min}$. Then, the weights on the right-hand side were slowly added in increments of $0.1 \mathrm{~g}$ until the tablet just

TABLE I - Composition of quetiapine fumarate (QF) buccal tablets

\begin{tabular}{lcccccccccc}
\hline Ingredients & F1 & F2 & F3 & F4 & F5 & F6 & F7 & F8 & F9 & F10 \\
\hline API (mg) & 25.00 & 25.00 & 25.00 & 25.00 & 25.00 & 25.00 & 25.00 & 25.00 & 25.00 & 25.00 \\
HPMC K4M (mg) & 50.00 & 37.50 & 25.00 & 18.75 & - & - & - & - & - & - \\
HPMC K15M (mg) & - & - & - & - & 25.00 & 18.75 & 12.50 & - & - & - \\
NaCMC (mg) & - & - & - & - & - & - & - & - & - & - \\
Carbopol (mg) & - & - & - & - & - & - & - & 10.00 & 10.00 & 5.00 \\
HPC (mg) & - & - & - & - & - & - & - & 40.00 & 15.00 & 20.00 \\
Perlitol (mg) & 42.00 & 54.50 & 67.00 & 73.25 & 67.00 & 73.25 & 79.50 & 42.00 & 67.00 & 67.00 \\
Magnesium stearate (mg) & 1.00 & 1.00 & 1.00 & 1.00 & 1.00 & 1.00 & 1.00 & 1.00 & 1.00 & 1.00 \\
Talc (mg) & 1.00 & 1.00 & 1.00 & 1.00 & 1.00 & 1.00 & 1.00 & 1.00 & 1.00 & 1.00 \\
Aspartame (mg) & 1.00 & 1.00 & 1.00 & 1.00 & 1.00 & 1.00 & 1.00 & 1.00 & 1.00 & 1.00 \\
Ethyl Cellulose(mg) & 30.00 & 30.00 & 30.00 & 30.00 & 30.00 & 30.00 & 30.00 & 30.00 & 30.00 & 30.00 \\
\hline All
\end{tabular}

*All the above formulations contains $1 \mathrm{mg}$ of Magnesium stearate, Talc and Aspartame and Total tablet weight is $150 \mathrm{mg}$.

* API-Active pharmaceutical ingredient, HPMCK4M-Hydroxy Propyl Methyl Cellulose K4M, NaCMC-Sodium Carboxy Methyl Cellulose, HPC-Hydroxy Propyl Cellulose, Perlitol as filler. 
separated from the membrane surface. The excess weight on the right pan, i.e., total weight minus $5 \mathrm{~g}$, was taken as a measure of the bioadhesive strength.

\section{Ex vivo residence time}

The ex vivo residence time of buccal tablets was determined using locally modified USP disintegration apparatus (Nakamura et al., 1996). The disintegration medium was $800 \mathrm{~mL}$ phosphate buffer, $\mathrm{pH} 6.6$ maintained at $37 \pm 0.2{ }^{\circ} \mathrm{C}$. The buccal membrane of porcine was tied to the surface of a glass slide vertically attached to the apparatus. One surface of tablet was hydrated using $0.5 \mathrm{~mL}$ of phosphate buffer, $\mathrm{pH} 6.6$ and then the hydrated surface was brought in contact with the mucosal membrane. The glass slide was vertically fixed to the apparatus and allowed to run in such way that the tablet completely immersed in the buffer solution at the lowest point and was out at the highest point. The time taken for complete erosion or displacement of the tablet from the mucosal surface was noted. The experiments were performed in triplicate $(n=3)$ and mean of triplicate was determined (Tanaka et al., 1980).

\section{Surface $\mathrm{pH}$ study}

The bioadhesive tablet was allowed to swell by keeping it in contact with $1 \mathrm{~mL}$ of distilled water for $2 \mathrm{~h}$ at room temperature. The $\mathrm{pH}$ was measured by bringing the $\mathrm{pH}$-meter electrode, in contact with the surface of the tablet and allowing it to equilibrate for $1 \mathrm{~min}$ (Bottenberg et al., 1991).

\section{Moisture absorption}

Agar $(5 \%, \mathrm{~m} / \mathrm{V})$ was dissolved in hot water and transferred into Petri dishes and allowed to solidify. Six buccal tablets from each formulation were placed in a vacuum oven overnight prior to the study to remove moisture, if any, and laminated on one side with a water impermeable backing membrane. They were then placed on the surface of the agar and incubated at $37^{\circ} \mathrm{C}$ for one hour. Then the tablets were removed and weighed and the percentage of moisture absorption was calculated (Agarwal, Mishra, 1999).

\section{In vitro drug release studies}

In vitro drug release studies were carried out by using USP XXIII rotating paddle method. The dissolution medium was $500 \mathrm{~mL}$ of phosphate buffer $\mathrm{pH} 6.6$ with $0.5 \%$ SLS at $50 \mathrm{rpm}$ maintained at $37 \pm 0.2^{\circ} \mathrm{C}$. The backing layer of tablet was attached to the glass slide with cyanoacrylate adhesive and then it was placed in dissolution vessel. Aliquot samples $(5 \mathrm{~mL})$ were withdrawn at predetermined time intervals and equivalent amount was replaced with fresh pre-warmed medium. The samples were filtered through whatman filter paper and analyzed at $250 \mathrm{~nm}$ using a UV-Visible spectrophotometer.

\section{Ex vivo permeation of buccal tablets}

Ex vivo permeation of QF from buccoadhesive matrix tablet through the porcine buccal membrane was studied by Franz diffusion cell. The membrane was mounted between donor compartment and receptor compartment. After the buccal membrane was equilibrated for $30 \mathrm{~min}$ with phosphate buffer, $\mathrm{pH} 6.6$ between both the compartments, receptor compartment was filled with fresh buffer solution, $\mathrm{pH}$ 6.6. The buccal tablet was placed in the donor chamber in such a way that core tablet attaches to the buccal membrane (Vamshi Vishnu, 2007.). Aliquot samples $(1 \mathrm{~mL})$ were withdrawn at predetermined time intervals and equivalent amount was replaced with fresh prewarmed medium. The samples were filtered through whatman filter paper and analyzed at $250 \mathrm{~nm}$ using a UV-Visible spectrophotometer.

\section{In vivo mucoadhesive performance of buccal tablets}

In vivo studies were performed by applying tablets to gums of five healthy volunteers (aged 22-26 years) to obtain the subjective parameters, the residence time and loss of the fragment and the possible production of irritation or pain. Optimized placebo (F3) tablet was given to volunteers and was asked to record the time of application and time of displacement of tablet and to collect information regarding parameters such as irritancy, comfort, taste, dry mouth, salivation and heaviness of the system at the place of application. Food intake was avoided from $0.5 \mathrm{~h}$ before beginning of the study to the end of the study but water intake is permitted after the initial $0.5 \mathrm{~h}$ (Periolia et al., 2004).

\section{FTIR studies}

The buccoadhesive tablets (F3) were compressed and powdered. The palletized powder, along with $\mathrm{KBr}$, was used for FTIR studies. The IR spectra were recorded using an IR-spectrophotometer (Perkin Elmer FT-IR, Perkin Elmer, USA) for drug (QF), HPMC K4M and optimized formulation.

\section{RESULTS AND DISCUSSIONS}

\section{Solubility studies}

Solubility of QF in the phosphate buffer, $\mathrm{pH} 6.6$ was conducted and it was found to be $3.4 \mathrm{mg} / \mathrm{mL}$. The study was conducted in phosphate buffer, pH 6.6 (Shanker 
TABLE II - Physico-chemical parameters of quetiapine fumarate buccal tablet

\begin{tabular}{cccccc}
\hline Formulation code & $\begin{array}{c}\text { Thickness } \\
(\mathrm{mm})\end{array}$ & $\begin{array}{c}\text { Weight Variation } \\
(\mathrm{mg})\end{array}$ & $\begin{array}{c}\text { Friability } \\
(\%)\end{array}$ & $\begin{array}{c}\text { Hardness } \\
\left(\mathrm{kg} / \mathrm{cm}^{2}\right)\end{array}$ & \%Drug content \\
\hline F1 & $2.69 \pm 0.020$ & $150.0 \pm 0.35$ & 0.08 & $6.4 \pm 0.12$ & 99.66 \\
F2 & $2.63 \pm 0.060$ & $148.1 \pm 0.70$ & 0.42 & $5.2 \pm 0.24$ & 101.10 \\
F3 & $2.51 \pm 0.024$ & $152.8 \pm 0.25$ & 0.06 & $7.7 \pm 0.10$ & 100.62 \\
F4 & $2.69 \pm 0.015$ & $149.2 \pm 0.55$ & 0.28 & $5.1 \pm 10.12$ & 99.63 \\
F5 & $2.36 \pm 0.020$ & $146.0 \pm 0.24$ & 0.17 & $4.8 \pm 0.33$ & 101.17 \\
F6 & $2.64 \pm 0.010$ & $155.2 \pm 0.70$ & 0.07 & $6.6 \pm 0.10$ & 99.04 \\
F7 & $2.71 \pm 0.030$ & $156.3 \pm 0.20$ & 0.31 & $5.1 \pm 0.05$ & 100.39 \\
F8 & $2.63 \pm 0.060$ & $148.1 \pm 0.70$ & 0.42 & $5.2 \pm 0.24$ & 101.10 \\
F9 & $2.61 \pm 0.030$ & $157.2 \pm 0.50$ & 0.23 & $4.5 \pm 0.05$ & 99.03 \\
F10 & $2.50 \pm 0.035$ & $153.5 \pm 0.15$ & 0.04 & $6.1 \pm 0.05$ & 100.43 \\
\hline
\end{tabular}

et al., 2009.). The flux and permeability coefficient of drug solution was found to be $0.3855 \mathrm{mg} \mathrm{h}^{-1} \mathrm{~cm}^{-2}$ and $0.01542 \mathrm{~cm} \mathrm{~h}^{-1}$, respectively.

\section{Thickness, weight variation, hardness, friability and assay}

The thickness, weight variation, hardness and assay of the buccal tablets (Table II) were found to be with in the prescribed limits. Hardness of the tablets was ranging from $4.5 \mathrm{~kg} \mathrm{~cm}^{-2}$ to $7.7 \mathrm{~kg} \mathrm{~cm}^{-2}$ as the compression force adjusted to meet the requirements of buccal bilayered tablets. Thickness of the tablets varied from $2.36 \mathrm{~mm}$ to $2.71 \mathrm{~mm}$ and compared with the theoretical value $(2.7 \mathrm{~mm})$. The assay values were also within the limits $99.04 \%-101.17 \%$ due to the proper blending of the drug and excipients. Friability of the tablets varied from 0.04 to $0.42 \%$ probably due to the good binding and compressibility of the selected excipients and drug.

\section{In vitro bioadhesion studies}

The bioadhesion strength, ex vivo residence time and surface $\mathrm{pH}$ of all formulation were given in Table III. Longer and Robinson (Longer, Robinson, 1986) defined the term bioadhesion as the attachment of a synthetic or natural macromolecule to mucus and/or an epithelial surface. Mucoadhesion takes place in four major stages: wetting, interpenetration, adsorption and formation of secondary chemical bonds between mucus membrane and polymer. The factors like molecular weight of the polymer, contact time with membrane, degree of swelling of the polymer and the type of biological membranes used in the study affect the strength of mucoadhesion (Park, Robinson, 1987). The maximum (41.1 mj) and minimum bioadhesion strength $(17.2 \mathrm{mj})$ was found in the formulation F8 and F4, respectively. The bioadhesion strength increased as the polymer concentration increased (Vamshi Vishnu et al., 2007). The order of bioadhesion was HPMC K4M $>$ HPMC $\mathrm{K} 15 \mathrm{M}>$ Carbopol. Formulations containing HPMC K15M and carbopol showed stronger bioadhesion strength than formulation containing HPMC K4M. Very strong bioadhesion could damage the epithelia of the buccal mucosa (Vamshi Vishnu et al., 2007). Carbopol 934 is reported to be responsible for the formation of the hydrogen bonds between the mucus and functional groups of the polymer. HPC was used to provide adhesion and controlled drug release.

\section{Ex vivo residence time}

The bioadhesion strength, ex vivo residence time and surface $\mathrm{pH}$ of all formulation were given in Table III. The minimum and maximum ex vivo residence time were found to be $4.05 \mathrm{~h}$ and $7.70 \mathrm{~h}$, respectively. The optimized formulation (F3) showed ex vivo residence time of 5.15h. As the polymer concentration increased, bioadhesion strength and ex vivo residence time increased (Vamshi Vishnu et al., 2007).

\section{Surface $\mathrm{pH}$ study}

The bio-adhesion strength, ex vivo residence time and surface $\mathrm{pH}$ of all formulation were given in Table III. In order to know the irritation potential in vivo, surface $\mathrm{pH}$ study was performed because acidic or alkaline $\mathrm{pH}$ may cause irritation to the mucosa. Surface $\mathrm{pH}$ of the optimized formulation $\mathrm{F} 3$ was found to be 7.18 (near to alkaline $\mathrm{pH}$ ) suggesting that it do not cause any irritation to the mucosa.

\section{Moisture absorption}

The moisture absorption studies of tablets give an 
TABLE III - The bioadhesive strength, residence time, surface $\mathrm{pH}$ and moisture absorbed values of quetiapine fumarate tablets

\begin{tabular}{ccccc}
\hline Formulation code & $\begin{array}{c}\text { Bio adhesion Strength } \\
(\mathrm{gm})\end{array}$ & $\begin{array}{c}\text { Ex vivo residence } \\
\text { time(hr) }\end{array}$ & Surface $\mathrm{pH}$ & $\begin{array}{c}\text { Moisture absorbed } \\
(\%)\end{array}$ \\
\hline F1 & $27.0 \pm 0.24$ & $6.14 \pm 0.23$ & $7.05 \pm 0.070$ & $29.6 \pm 1.2$ \\
F2 & $20.6 \pm 0.34$ & $5.70 \pm 0.16$ & $5.91 \pm 0.010$ & $30.3 \pm 3.5$ \\
F3 & $19.8 \pm 0.04$ & $5.15 \pm 0.20$ & $7.18 \pm 0.085$ & $32.2 \pm 1.4$ \\
F4 & $17.2 \pm 0.19$ & $4.05 \pm 0.25$ & $6.21 \pm 0.015$ & $43 . \pm 2.7$ \\
F5 & $29.3 \pm 0.06$ & $6.74 \pm 0.14$ & $6.81 \pm 0.035$ & $31.5 \pm 1.6$ \\
F6 & $25.5 \pm 0.07$ & $6.26 \pm 0.31$ & $6.85 \pm 0.015$ & $36.9 \pm 0.9$ \\
F7 & $21.0 \pm 0.21$ & $5.15 \pm 0.35$ & $6.13 \pm 0.010$ & $47.8 \pm 1.9$ \\
F8 & $41.1 \pm 0.27$ & $7.70 \pm 0.15$ & $6.92 \pm 0.015$ & $52.3 \pm 2.6$ \\
F9 & $40.8 \pm 0.07$ & $7.03 \pm 0.25$ & $6.85 \pm 0.030$ & $68.1 \pm 1.5$ \\
F10 & $37.0 \pm 0.18$ & $6.25 \pm 0.35$ & $6.63 \pm 0.050$ & $71.7 \pm 2.9$ \\
\hline
\end{tabular}

indication of the relative moisture absorption capacities of polymers and whether the formulations would maintain their integrity after moisture absorption. The order of increasing moisture absorption was HPMC K4M $<$ HPMC K15M $<$ Carbopol 934 (Table III). The higher moisture absorption of Carbopol 934 may be due its predominant hydrophilic nature.

\section{In vitro drug release studies}

The in vitro drug release profiles of all formulations were shown in Figure 1. The drug release from buccoadhesive tablets observed to be varied according to the type and ratio of matrix forming polymers. Formulations
F3 and F7 showed burst release which was due to lower concentration of HPMC K4M and HPMC K15M. An increase in polymer concentration resulted in an increase in the viscosity of the gel and creates thick gel barrier with longer diffusional path length leading to decrease in diffusion coefficient of the drug and hence a reduction in cumulative percentage of drug release (F5 and F6). Tablets containing lower concentration of either HPMC K4M, HPMC K15M or carbopol 934P respectively have shown a tendency to release the drug in shorter time periods, while the release slowed down as the concentration of the polymer increased.

Formulation F3 $(91.7 \pm 0.51 \%)$ composed of $1: 1$

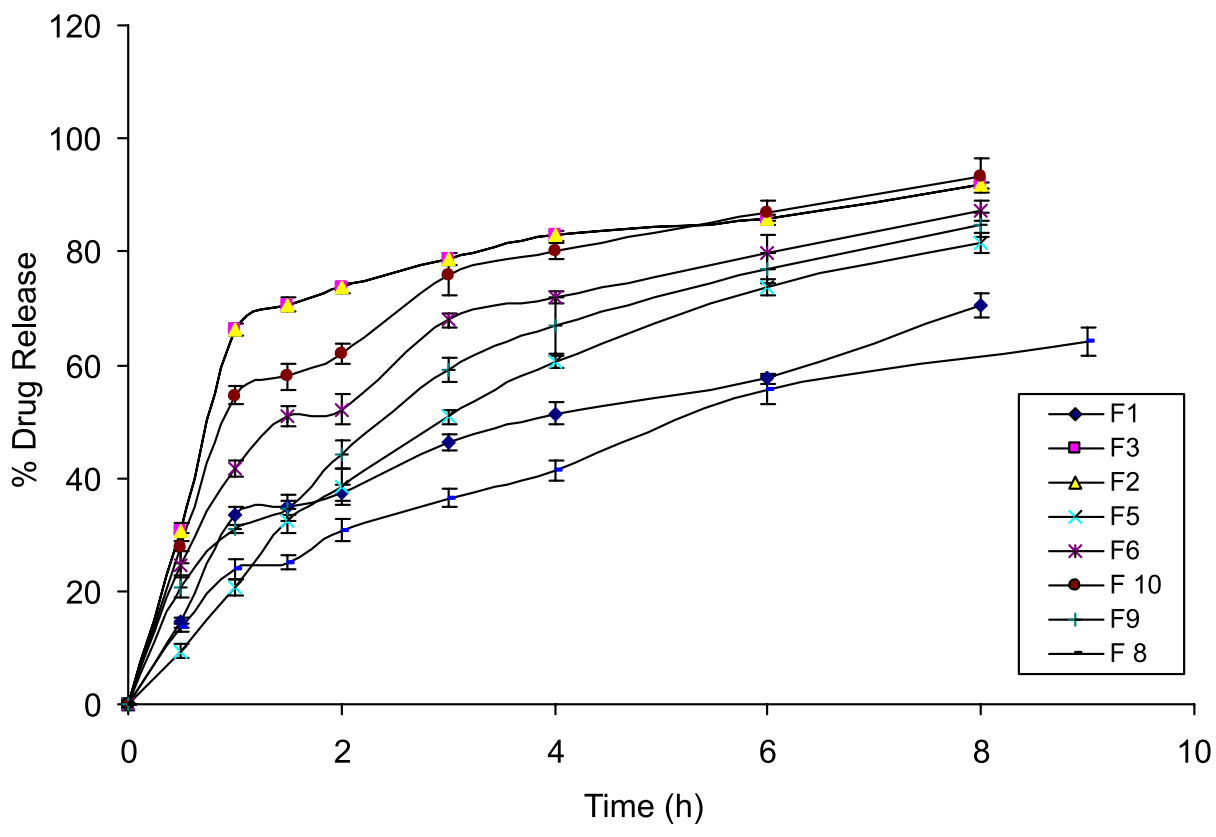

FIGURE 1 - Mathematical model fitting of in vitro drug release. 
TABLE IV - Release kinetics and mechanism of optimized formulation

\begin{tabular}{cccccc}
\hline \multirow{2}{*}{ Formulation code } & \multicolumn{5}{c}{ Mathematical models(Kinetics) } \\
\cline { 2 - 6 } & Zero order & First order & Higuchi & \multicolumn{2}{c}{ Peppas model } \\
\hline \multirow{2}{*}{ F3 } & $\mathrm{R}^{2}$ & $\mathrm{R}^{2}$ & $\mathrm{R}^{2}$ & $\mathrm{n}$ & $\mathrm{R}^{2}$ \\
\cline { 2 - 6 } & 0.9988 & 0.9950 & 0.9913 & 0.398 & 0.9965 \\
\hline
\end{tabular}

drug: HPMC K4M ratio; F6 (87.1 $\pm 1.84 \%)$ 1:0.75 drug: HPMC K15M ratio and F10 $(93.4 \pm 3.06 \%)$ containing carbopol 934P (5mg) and HPC (20mg) showed maximum release among their respective series. Optimized formulation (F3) was containing the less quantity (25 mg) of HPMC K4M, and achieved the required bio adhesive and other properties required for buccal tablets compared to rest of the formulations. Hence, it was selected as optimized formulation. F4 and F7 formulations containing 1:0.75 drug: HPMC K4M and 1:0.5 drug: HPMC K15M disintegrated with in 4 hrs because of low concentration of polymer. Increasing the concentration of the polymer in the formulations showed a sustained effect on QF release. The rapidly hydrating polymer dominated in controlling the release of QF from the buccal tablets, as seen from the dissolution profiles and moisture absorption data. Release rates slowed down when the concentration of HPMC K4M or HPMC K15M or Carbopol 934P increased from $1: 1$ to $1: 2$ ratios and $1: 0.5$ to $1: 1$ in $F 1-4, F 8-10$ and $F 5-7$, respectively. This is because as the proportion of these polymers in the matrix increased, there was an increase in the amount of water uptake and proportionally greater swelling leading to a thicker gel layer.

\section{Mathematical model fitting of in vitro drug release}

The in vitro percentage drug release of optimized formulation F3 was attempted to fit into mathematical models. The $\mathrm{n}$ and $\mathrm{R}^{2}$ values for zero-order, first-order and Higuchi and Peppas (Costa, Sousa Lobo, 2001) were represented in Table IV. The Peppas model is widely used, when the release mechanism is not well known and when more than one type of release is involved (Peppas,1985). The semiempirical equation is shown as Eq. 3:

$$
\mathrm{Mt} / \mathrm{M} \infty=\mathrm{kt}^{\mathrm{n}}
$$

Where $\mathrm{Mt} / \mathrm{M} \infty$ is fraction of the drug released at time $\mathrm{t}$; $\mathrm{k}$ represents a constant, incorporating structural and geometrical characteristics of the buccal devices; and $n$ is the diffusion exponent, which characterizes the type of release mechanism during the dissolution process. For non-Fickian release, the value of $\mathrm{n}$ falls between 0.5 and 1.0 , while in case of Fickian diffusion, $\mathrm{n}=0.5$; for zero order release (case II transport), $\mathrm{n}=1$; and for supercase II transport, $\mathrm{n}$ is greater than 1 . Observation of all the $\mathrm{R}^{2}$ values indicated that the highest $\mathrm{R}^{2}(0.9988)$ value was found for Zero order release. According to ' $n$ ' value it is less than 0.5 , so it follows fickian diffusion with zero order release.

\section{Ex vivo permeation of buccal tablets}

Based on in vitro drug release studies and the results obtained therein and bioadhesion strength of all formulations, formulation $\mathrm{F} 3$ was selected for ex vivo permeation study. Porcine buccal mucosa resembles that of the human in terms of structure and composition. Hence, porcine buccal mucosa was selected for study. The flux, permeability coefficient and cumulative drug permeated from formulation $\mathrm{F} 3$ with enhancer were found to $0.398 \mathrm{mg} \mathrm{h}^{-1} \mathrm{~cm}^{-2}$, $0.015528 \mathrm{~cm} / \mathrm{h}$ and $67.2 \pm 0.4 \%$ respectively. The flux, permeability coefficient for drug solution and formulation F3 with sodium deoxycholate enhancer and without enhancer were shown in Table V. Presence of enhancer (sodium deoxycholate) increases the diffusivity of the drug via transcellular and paracellular routes. This is due to extraction of lipids from the cell membrane along with the extraction of mucosal lipid from the intercellular spaces by the formation of micelles (Hoogstraate et al., 1997.) and causing uncoiling and extension of the protein helices leading to opening of the polar pathways for diffusion. All these effects increase the permeation of the drug. Cumulative percentage drug permeated of $\mathrm{F} 3$ formulation was shown in Figure 2.

TABLE V - Flux and Permeability coefficient values of drug solution and formulation

\begin{tabular}{lcc}
\hline Formulation code & $\begin{array}{c}\text { Flux } \\
\left(\mathrm{mg} \mathrm{h}^{-1} \mathrm{~cm}^{-2}\right)\end{array}$ & $\begin{array}{c}\text { permeability } \\
\text { coefficient }(\mathrm{cm} / \mathrm{h})\end{array}$ \\
\hline Drug solution & 0.385 & 0.01542 \\
F3 without enhancer & 0.326 & 0.01305 \\
F3 with enhancer & 0.398 & 0.015528 \\
\hline
\end{tabular}

Porcine buccal mucosa resembles that of the human in terms of structure and composition. Hence, 


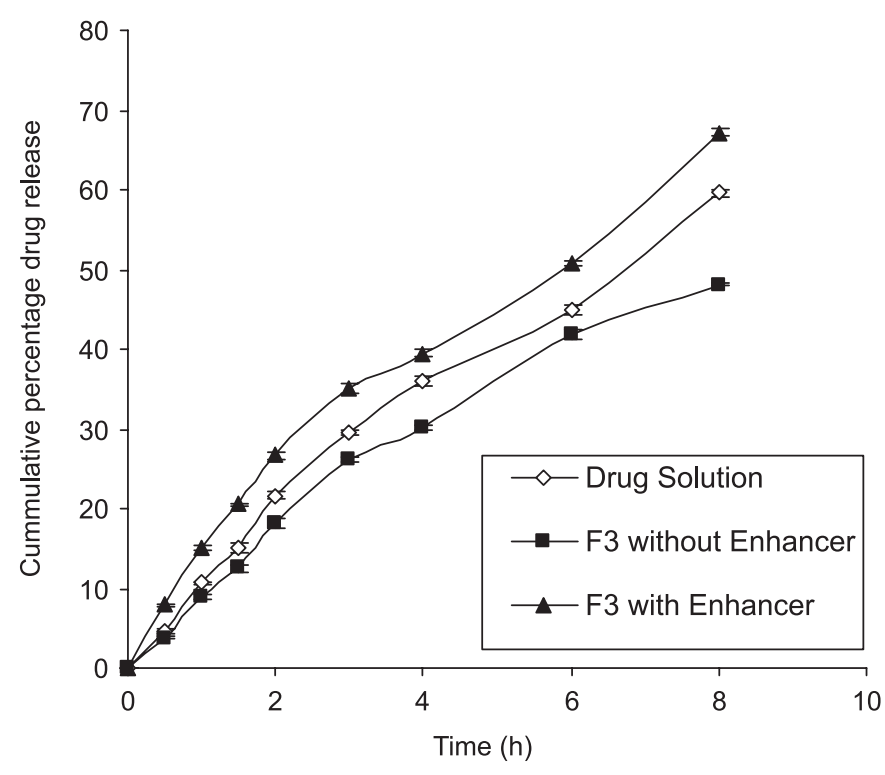

FIGURE 2 - In vitro Drug Release of Optimized formulation with Enhancer, Without Enhancer and Drug Solution.

porcine buccal mucosa was selected for the study. The flux, permeability coefficient and cumulative drug permeated from formulation F3 with enhancer were found to $0.398 \mathrm{mg} \mathrm{h}^{-1} \mathrm{~cm}^{-2}, 0.015528 \mathrm{~cm} / \mathrm{h}$ and $67.2 \pm 0.4 \%$, respectively. The flux, permeability coefficient for drug solution and formulation F3 with enhancer and without enhancer were shown in Table V. Presence of enhancer (sodium deoxycholate) increases the diffusivity of the drug via transcellular and paracellular routes. This is due to the extraction of lipids from the cell membrane along with the extraction of mucosal lipids as a result of formation of micelles (Hoogstraate et al.,1997.) and causing uncoiling and extension of the protein helices leading to opening of the polar pathways for diffusion. All these effects collectively contributed in enhancing the permeation of the drug. Cumulative percentage of drug permeated of F3 formulation was shown in Figure 2.

In vivo mucoadhesive performance of buccal tablets

The results of volunteers to each subjective parameter was shown in Table VI. From the study, it was observed that slight bitter taste was perceived at $4 \mathrm{~h}$ due to higher swelling of polymer which is responsible for increased thickness of the buccal tablet and this led to improved radial release of QF. This radial release might be responsible for slight bitter taste.

\section{FTIR studies}

FTIR spectra of Quetiapine Fumarate (Figure 3 A) showed peaks of 3310, 2941, 1741, 1597, 1371 and
TABLE VI - Response of Healthy Human Male Volunteers to Various Subjective Parameters $(\mathrm{n}=3$ )

\begin{tabular}{|c|c|c|}
\hline S. NO. & Criteria & $\begin{array}{l}\text { Volunteer's } \\
\text { response (\%) }\end{array}$ \\
\hline \multirow[t]{5}{*}{1} & Irritation & \\
\hline & None & 100 \\
\hline & Slight & - \\
\hline & Moderate & - \\
\hline & Severe & - \\
\hline \multirow[t]{5}{*}{2} & Taste & \\
\hline & Normal & 85 \\
\hline & Slightly & 15 \\
\hline & Very unpleasant & - \\
\hline & Pleasant & - \\
\hline \multirow[t]{6}{*}{3} & Comfort & \\
\hline & Very comfortable & - \\
\hline & Comfortable & 90 \\
\hline & Slightly uncomfortable & 10 \\
\hline & Moderately uncomfortable & - \\
\hline & Severely uncomfortable & - \\
\hline \multirow[t]{5}{*}{4} & Dryness of mouth & \\
\hline & None & 85 \\
\hline & Slight & 15 \\
\hline & Moderate & - \\
\hline & Severe & - \\
\hline \multirow[t]{5}{*}{5} & Salivary secretion & \\
\hline & None & 30 \\
\hline & Slight & 50 \\
\hline & Moderate & 20 \\
\hline & Severe & - \\
\hline \multirow[t]{5}{*}{6} & $\begin{array}{l}\text { Heaviness at the place of } \\
\text { attachment }\end{array}$ & \\
\hline & None & 95 \\
\hline & Slight & 5 \\
\hline & Moderate & - \\
\hline & Severe & - \\
\hline \multirow[t]{3}{*}{7} & $\begin{array}{l}\text { Dislodgement of the system } \\
\text { during study }\end{array}$ & \\
\hline & No & 100 \\
\hline & Yes & - \\
\hline
\end{tabular}




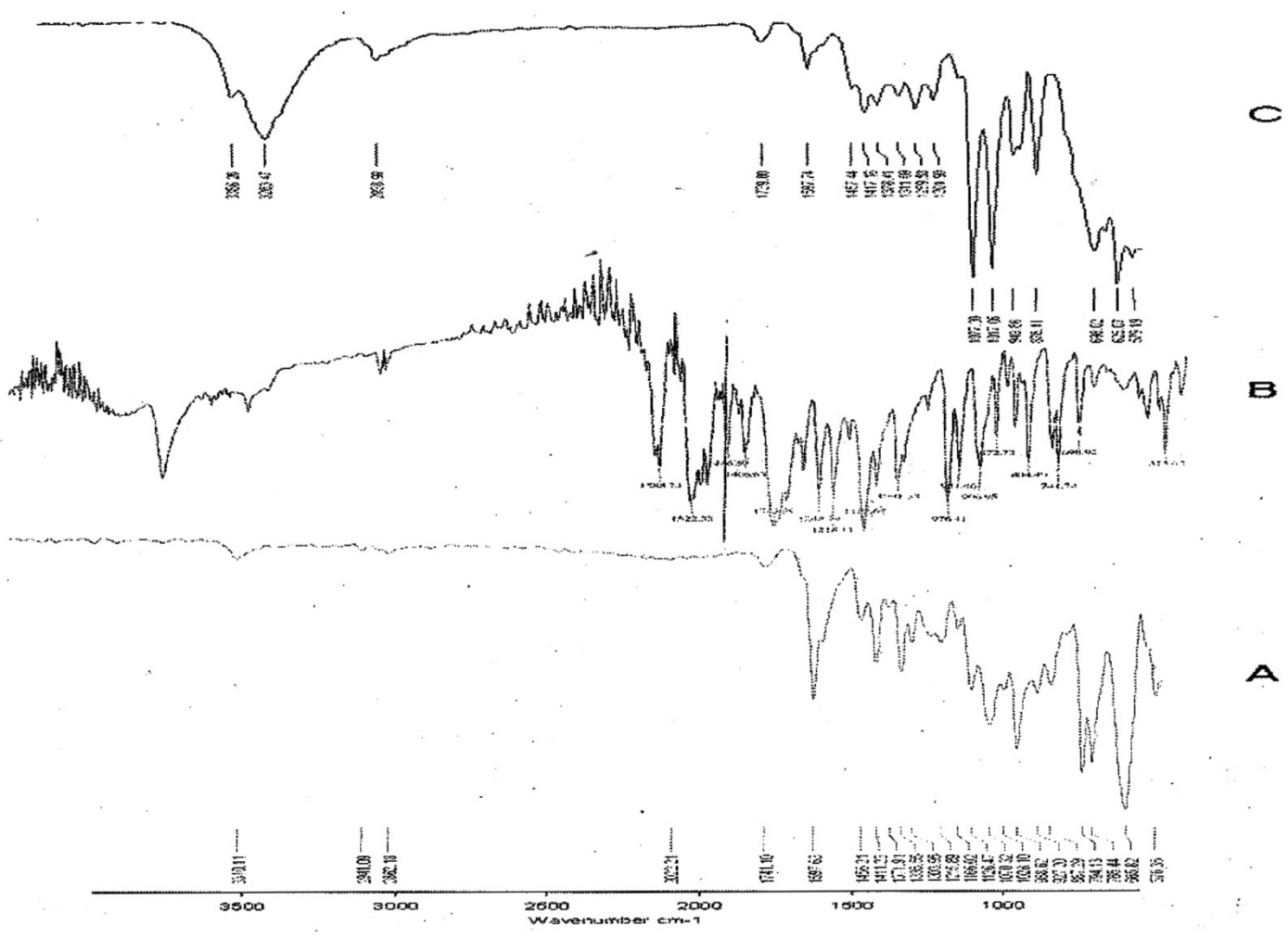

FIGURE 3 - FTIR spectra of A) Drug (quetiapine fumarate), B) Polymer (HPMC K4M), C) Optimized formulation.

$1070 \mathrm{~cm}^{-1}$ due to $-\mathrm{OH}$ stretching, $\mathrm{C}-\mathrm{H}$ stretching, $\mathrm{C}=\mathrm{O}$ stretching, $\mathrm{N}-\mathrm{H}$ bending, $\mathrm{C}-\mathrm{H}$ bend in plane and $\mathrm{C}-\mathrm{C}$ stretching respectively.

FTIR Spectra of HPMC K4M (Figure 3 B) showed peaks of 3283, 1446, 1407, 1248, 951 and $872 \mathrm{~cm}^{-1}$ due to $\mathrm{C}-\mathrm{H}$ stretching, $\mathrm{O}-\mathrm{H}$ stretching and $\mathrm{C}-\mathrm{C}$ stretching respectively.

FTIR spectra of optimized formulation (Figure $3 \mathrm{C}$ ) showed both characteristics peaks of drug and polymer indicating no drug-polymer interaction.

\section{CONCLUSION}

The present work was aimed at developing a buccoadhesive Quetiapine Fumarate tablets. Progressive hydration technology was employed by using various grades of HPMC in combination with carbopol and HPC for their reported buccoadhesive and release rate controlling abilities. Directly compressed optimized formulation F3 containing HPMC K4M in a drug: polymer ratio (1:1) showed good bioadhesive strength, $91.5 \%$ in vitro drug release in 8 hours and $85 \%$ permeation through porcine buccal mucosa. These findings suggested that buccoadhesive tablets of Quetiapine Fumarate tablets could be prepared by employing direct compression method and improvement in drug permeation through buccal mucosa contributing to significant improvement in oral bio availability of the drug.

\section{REFERENCES}

AGARWAL, V.; MISHRA, B. Design, development and biopharmaceutical properties of buccoadhesive compacts of pentazocine. Drug Dev. Ind. Pharm., v.25, p.701-709, 1999.

AKBARI, J.; NOKHODCHI, A.; FARID, D.; ADRANGUI, M.; SIAHI-SHADBAD, M. R.; SAEEDI, M. Development and evaluation of buccoadhesive propranolol hydrochloride tablet formulations: effect of fillers. Farmaco, v. 59, p.155$161,2004$.

ANDERS, R.; MERKLE, H.P. Evaluation of laminated mucoadhesive patches for buccal drug delivery. Int. J. Pharm., v.49, p.231-240, 1989.

AUNGST, B.J.; ROGERS. N.J. Comparison of the effects of various transmucosal absorption promoters on buccal insulin delivery. Int. J. Pharm., v.53, p.227-235, 1989. 
BHANUDAS, S.K.; SANJAY, P. Preformulation and formulation studies of novel $\mathrm{pH}$ independent controlled release drug delivery system of quetiapine fumarate. $J$. Pharm. Res., v.2, p.110-119, 2009.

BOTTENBERG, P.; CLEYMAET, R.; MUYNEK, C.D.; REMON, J.P.; COOMANS, D.; SLOP, D. Development and testing of bioadhesive, fluoridecontaining slow-release tablets for oral use. J. Pharm. Pharmacol., v.43,p.457-464, 1991.

BREMECKER, K.D.; STREMPEL, H.; KLEIN, G. Novel concept for a mucosal adhesive ointment. J. Pharm. Sci., v.73, p.548-552, 1984.

BURNSIDE, B.A.; KEITH, A.D.; SNIPES. W. Microporous hollow fibers as a peptide delivery system via the buccal cavity. Proc. Int. Symp. Control. Release Bioact. Mater., v.16, p.93-94, 1989.

COSTA, P.; SOUSA LOBO, J.M. Modeling and comparison of dissolution profiles. Eur. J. Pharm. Sci., v.3, p.123-133, 2001.

EBERT, C.D.; HEIBER, S.J.; DAVE, S.C.; KIM, S.W.; MIX, D. Mucosal delivery of macromolecules. J. Control Release, v.28, p.37-44, 1994.

GIBALDI, M. The number of drugs administered buccally is increasing. Clin. Pharmacol., v.3, p.49-56, 1985.

GUO, J.H. Bioadhesive polymer buccal patches for buprenorphine controlled delivery formulation, in vitro adhesion and release properties. Drug Dev. Ind. Pharm., v.20, p.2809-2821, 1994.

GUPTA, A.; GARG, S.; KHAR. R.K. Measurement of bioadhesive strength of mucoadhesive buccal tablets: design of an in vitro assembly. Ind. Drugs, v.30, p.152-155, 1993.

HOOGSTRAATE, A.J.; WERTZ, P.W.; SQUIER, C.A.; BOS VAN GEEST, A.; ABRAHAM, W.; GARRISON, M.D.; VERHOEF, J.C.; JUNGINGER, H.E.; BODDE, E.E. Effects of the penetration enhancer glycodeoxycholate on the lipid integrity in porcine buccal epithelium in vitro. Eur. J. Pharm. Sci., v.5, p.189-198, 1997.

ISHIDA, M.; VAMBU, N.; VAGAI, R. Highly viscous gel ointment containing carbopol for application to the oral mucosa. Chem. Pharm. Bull., v.31, p.4561-4564, 1983.
LONGER, M.A.; ROBINSON, J.R. Fundamental aspects of bioadhesion. Pharm. Int., v.7, p.114-117, 1986.

LEE, V.H.L.; YAMAMOTO, A.; KOMPELLA. U.B. Mucosal penetration enhancers for facilitation of peptide and protein drug absorption. Crit. Rev. Ther. Drug Carrier Syst., v.8, p.191-192, 1991.

NAGAI, T.; MACHIDA. Y. Advances in drug delivery: mucosal adhesive dosage forms. Pharm Int., v.6, p.196-200, 1985.

NAKAMURA, F.; OHTA, R.; MACHIDA, Y.; NAGAI. T. In vitro and in vivo nasal mucoadhesion of water soluble polymers. Int. J. Pharm., v.134, p.173-181,1996.

OWENS, T.S.; DANSEREAU, R.J.; SAKR, A. Development and evaluation of extended release bioadhesive sodium fluoride tablets. Int. J. Pharm. v.288, p.109-122, 2005.

PACKER, M.; COATS, A.J.S.; FOWLER, M.B.; KATUS, H.A.; KRUM, H.; MOHACSI, P.; ROULEAU, J.L.; ENDERA, M.T.; CASTAIGNE, A.; ROECKER, E.B.; SCHULTZ, M.K.; DEMETS, D.L. Effect of carvedilol on survival in severe chronic heart failure. N. Engl. J. Med., v.344, p.1651$1658,2001$.

PARK, H.; ROBINSON, J. R. Mechanisms of mucoadhesion of poly (acrylic acid) hydrogels. Pharm. Res., v.4, p.457464, 1987.

PEPPAS. N.A. Analysis of fickian and non-fickian drug release from polymers. Pharm. Acta Helv., v.60, p.110-111, 1985.

PERIOLIA, L.; AMBROGIA, V.; ANGELICIA, F.; RICCIA, M.; GIOVAGNOLIA, S.; CAPUCCELLAB, M.; ROSSIA. C. Development of mucoadhesive patches for buccal administration of ibuprofen. J. Control. Release, v.99, p.73-82, 2004.

PITHA, J.; HARMAN, S.M.; MICHEL, M.E. Hydrophilic cyclodextrin derivatives enable effective oral administration of steroidal hormones. J. Pharm. Sci., v.75, p.165-167, 1986.

SCHOR, J.M.; DAVIS, S.S.; BOLTON, S.; NIGALAYE, A. Susadrin transmucosal tablets. Drug. Dev. Ind. Pharm. v.9, p.1359-1377, 1983.

SENEL, S.; HINCAL, A.A. Drug penetration enhancement via buccal route: possibilities and limitations. J. Control. Release, v.72, p.133-144, 2001. 
SHANKER, G.; CHEGONDA KUMAR, K.; CHANDRA SEKHARARAO, G.; VIJAYAKUMAR, B.; PRABHAKAR REDDY, V. Formulation and evaluation of bioadhesive buccal drug delivery of tizanidine hydrochloride tablets. AAPS PharmSciTech., v.10, p.124-134, 2009.

SHOJAEI. A. H. Buccal mucosa as a route for systemic drug delivery: a review. J. Pharm. Pharmaceut. Sci., v.1, p.1530, 1998.

SQUIER, C.A.; WERTZ. P.W. Structure and function of the oral mucosa and implications for drug delivery. In: RATHBONE, M.J. (Ed.). Oral mucosal drug delivery. New York: Marcel Dekker, 1996. p.1-2.

STEWARD, A.; BAYLEY, D.L.; HOWES. C. The effect of enhancers on the buccal absorption of hybrid (BDBB) alpha interferon. Int. J. Pharm., v.104, p.145-149, 1994.
TANAKA, M.; YANAGIBASHI, N.; FUKUDA, H.; NAGAI, T. Absorption ofsalicylic acid through the oral mucous membrane of hamster cheek pouch. Chem. Pharm. Bull. (Tokyo), v.28, p.1056-1061, 1980.

VAMSHI VISHNU, Y.; RAMESH, G.; CHANDRASEKHAR, K.; BHANOJI RAO, M. E.; MADHUSUDAN RAO, Y. Development and in vitro evaluation of buccoadhesive carvedilol tablets. Acta Pharm., v.57, p.185-197, 2007.

ZHANG, J.; NIU, S.; EBERT, C.; STANLEY, T.H. An in-vivo dog model for studying recovering kinetics of the buccal mucosa permeation barrier after exposure to permeation enhancers: apparent evidence of effective enhancement without tissue damage. Int. J. Pharm., v.101, p.15-22, 1994.

Received for publication on 02 ${ }^{\text {nd }}$ Mach 2011 Accepted for publication on $11^{\text {th }}$ October 2012 
